\title{
Hydration and Strength Evolution of Ternary-Blend High-Volume Fly Ash Concretes
}

\author{
by C. Gunasekera, Z. Zhou, M. Sođ, D. W. Law, S. Setunge, and P. Mendis
}

The increase of carbon emissions due to the annual growth of portland cement $(P C)$ production has promoted research into the development of sustainable green concrete using a range of readily available industrial waste materials. The present study is focused on developing two high-volume fly ash (HVFA) concretes with cement replacement levels of 65\% (HVFA-65) and 80\% (HVFA-80). The required lime for both HVFA concrete mixtures was initially determined and the optimized mixture designs identified, based on the 28-day compressive strength, by varying the low-calcium Class F fly ash-hydrated lime composition. The optimized concrete mixtures achieved a compressive strength of 53 and $40 \mathrm{MPa}$ (7.69 and $5.80 \mathrm{ksi}$ ) for HVFA-65 and HVFA-80 concretes, respectively. The early-stage strength development is dependent on the matrix produced in the specific HVFA concrete, which is itself dependent on the number of unreacted fly ash spheres. The increase of fly ash and hydrated lime dosage in HVFA concrete increases the rate of hydration of the $C_{3} A$ and $C_{4} A F$ phases, but decreases the hydration of the $C_{3} S$ phase, which resulted in lower early-age strength development than occurs in PC concrete. It was noted that the initial setting time of HVFA concretes increase with an increase of fly ash content. However, addition of hydrated lime accelerates the hydration and decreases the final setting time for HVFA concretes.

Keywords: compressive strength; high-volume fly ash concrete; hydration; portland cement; pozzolanic index; sustainability.

\section{INTRODUCTION}

Concrete is one of the most widely used construction materials and, at the present time, annual world consumption is approximately 25 Giga tonnes. ${ }^{1}$ Portland cement (PC) is the major binder component. The manufacturing process is energy-intensive, contributing 1.6 billion tonnes of greenhouse gas emission globally per annum. It is well known that 0.6 to $0.8 \mathrm{~kg}$ ( 1.3 to $1.8 \mathrm{lb})$ of $\mathrm{CO}_{2}$ is emitted into the atmosphere for every kilogram $(2.2 \mathrm{lb})$ of cement manufactured..$^{2-4}$ In Australia alone, the total greenhouse gas emissions from cement production has increased by $6.7 \%$ between 2005 and 2015. Additionally, 1 tonne of cement production requires about 2.8 tonnes of limestone, fuel, and other raw materials. Thus, the reduction of carbon emission related to construction is imperative as current cement production alone contributes approximately 5 to $7 \%$ of anthropogenic $\mathrm{CO}_{2}$ emissions worldwide. The damage that this level of pollution is causing to the atmosphere is unsustainable. Therefore, there is great interest in environmentally friendly concrete with high-volume fly ash (HVFA), which is an abundantly available industrial waste material.
Fly ash is precipitated electrostatically or mechanically from the exhaust gasses or coal-fired power stations. Estimated annual worldwide generation of fly ash in 2012 was approximately 750 million tonnes, while annual fly ash production in Australia stands at 14.5 million tonnes, which is projected to reach 20 million tonnes in $2025 .{ }^{5}$ The use of fly ash in cement and concrete manufacturing is estimated to be close to $20 \%$ of annual production, with another $25 \%$ used for low value-added applications. The balance is placed into long-term storage, which incurs intensive environmental and operational cost frameworks as landfill. The increasing quantity of toxic metals in the landfill potentially increases the threat to groundwater contamination while posing a significant risk to local aquifers due to the possible leaching of heavy metals. ${ }^{6}$ Hence, a reduction of cement production by replacement with fly ash in concrete would provide significant socio-economic and environmental benefits.

The use of concrete containing HVFA has recently gained popularity as a resource-efficient, durable, and sustainable option for a variety of concrete applications..$^{7-10}$ HVFA concrete is a concrete generally defined as that with at least $50 \%$ of the PC replaced with fly ash. ${ }^{11}$ However, a major drawback for HVFA concrete is low early strength development when replacement levels exceed $40 \% .{ }^{12-14}$ When fly ash is added in the concrete mixture, it will ultimately reduce the porosity. However, the reaction rate is slower than that of cement. At very early ages, it acts as a filler. ${ }^{15}$ The filler effect acts in three ways: 1) higher separation among cement particles may promote complete cement hydration due to the availability of more space; 2) the partial deflocculation of the cement particles in the three-dimensional (3-D) network providing increased cement particle surface area; and 3) provision of new nucleation sites on fly ash spheres that can promote the formation of more hydration products. ${ }^{15,16}$ However, the pozzolanic reaction of fly ash being a slow process, its contribution toward strength development occurs at later ages and, hence, the early-age strength of HVFA concrete is significantly reduced. ${ }^{17,18}$ This is due to the unavailability of sufficient quantities of $\mathrm{Ca}(\mathrm{OH})_{2}$ to react with the low-calcium Class F fly ash particles. Hence, there is a possibility of improving the pozzolanic reaction of 
Table 1-Chemical composition

\begin{tabular}{|c|c|c|c|c|c|c|c|c|c|c|c|c|}
\hline \multirow[b]{2}{*}{ Material } & \multicolumn{12}{|c|}{ By weight, $\%$} \\
\hline & $\mathrm{SiO}_{2}$ & $\mathrm{Al}_{2} \mathrm{O}_{3}$ & $\mathrm{Fe}_{2} \mathrm{O}_{3}$ & $\mathrm{CaO}$ & $\mathrm{P}_{2} \mathrm{O}_{5}$ & $\mathrm{TiO}_{2}$ & $\mathrm{MgO}$ & $\mathrm{K}_{2} \mathrm{O}$ & $\mathrm{SO}_{3}$ & $\mathrm{MnO}$ & $\mathrm{Na}_{2} \mathrm{O}$ & $\mathrm{LOI}^{*}$ \\
\hline $\mathrm{PC}$ & 22.5 & 4.5 & 0.4 & 66.3 & 0.67 & 0.20 & 0.51 & 0.15 & 2.8 & 0.10 & 0.17 & 1.7 \\
\hline HL & 0.85 & 0.45 & 0.55 & 96.25 & 0.80 & 0 & 1.10 & 0 & 0 & 0 & 0 & 0 \\
\hline
\end{tabular}

*Loss on ignition (unburnt carbon content).

fly ash by adding $\mathrm{Ca}(\mathrm{OH})_{2}$ externally to the fly ash-cement mixture through hydrated lime. ${ }^{12,19}$

Shafigh et al. ${ }^{20}$ worked with HVFA concrete containing $50 \%$ low-calcium Class F fly ash and observed compressive strengths of 22.1 and $41.5 \mathrm{MPa}(3.2$ and $6.0 \mathrm{ksi})$ at 7 and 90 days, respectively. Babu et al. ${ }^{21}$ showed that lightweight HVFA concrete with a density of $1725 \mathrm{~kg} / \mathrm{m}^{3}\left(108 \mathrm{lb} / \mathrm{ft}^{3}\right)$ and the 28- and 90-day compressive strengths of 12.5 and $16 \mathrm{MPa}$ (1.8 and $2.3 \mathrm{ksi}$ ), respectively, can be produced using $309 \mathrm{~kg}(681 \mathrm{lb})$ of PC and $309 \mathrm{~kg}(681 \mathrm{lb})$ of lowcalcium Class $\mathrm{F}$ fly ash in the concrete mixture. Kumar et al. ${ }^{22}$ also studied HVFA concrete containing 50\% low-calcium Class F fly ash and showed that compressive strength varied between 20 and $55 \mathrm{MPa}$ (2.9 and $8.0 \mathrm{ksi})$ at a water-cement ratio $(w / c)$ of 0.4 , and 32 to $80 \mathrm{MPa}$ (4.6 to $11.6 \mathrm{ksi}$ ) at a $w / c$ of 0.3 , over a 7- to 365-day period. Arel and Aydin ${ }^{23}$ examined the effects of high proportions of low-calcium Class F fly ash in cement-paste composites and concluded that composites with $75 \%$ replacement of cement by fly ash are potentially suitable for low-strength applications. The authors ${ }^{23}$ further noted that the low-calcium Class F fly ash-lime reaction produce a densified cement matrix, but the addition of silica fume weakened the bond between the fly ash particles and the surrounding matrix, causing a reduction in strength evolution. This is primarily due to the sparse availability of portlandite $\left(\mathrm{Ca}(\mathrm{OH})_{2}\right)$ in the system, which limits the formation of pozzolanic hydrated calcium silicate hydrate (C-S-H) gel. On the other hand, De la Varga et al. ${ }^{15}$ studied the cement hydration of HVFA mortar produced with $60 \%$ and $80 \%$ high-calcium Class C fly ash, and observed that the increased spacing of cement and nucleation/deflocculation effects provided by the addition of fly ash are dominant when compared with the chemical effect (that is, high-calcium fly ash reactivity) at very early ages (less than 48 hours), in particular for the mixtures with higher fly ash replacement levels. After 48 hours, the mixtures containing fly ash exhibited a greater cumulative heat release, which indicates a greater extent of hydration reaction.

The alkali activation of $100 \%$ fly ash in geopolymer concrete requires elevated temperature curing, ${ }^{24,25}$ which accelerated the polymerization in a high-pH environment and hydrothermal conditions. ${ }^{26-29}$ The use of HVFA concrete can be beneficial where ambient temperature curing enables setting of the concrete. This study focused on developing two HVFA concrete mixtures that contain 65\% (HVFA-65) and $80 \%$ (HVFA- 80 ) of the cement replaced with low-calcium Class F fly ash and hydrated lime. The strength activity index was calculated using the mortar compressive strength. These results are then used to determine the pozzolanic index and calculate the required lime for HVFA-65 and HVFA- 80 concretes. A series of HVFA-65 and HVFA-80 concrete specimens were then prepared by varying the low-calcium Class F fly ash-lime combination, and the strength development examined over the period 3 to 90 days. The hydration pattern of HVFA-65 and HVFA-80 pastes with optimized strengths are investigated by isothermal calorimetry, thermogravimetric analysis (TGA), X-ray diffraction (XRD), and scanning election microscopy (SEM) techniques. The time required for the HVFA pastes with optimized strength to set are determined using Automatic Vicat needle apparatus.

\section{RESEARCH SIGNIFICANCE}

Published research on HVFA concrete to date has primarily considered cement replacements of up to $60 \%$ by fly ash. Minimal research has been conducted on the reaction mechanisms, strength evolution, and microstructure development of HVFA at higher replacements levels. The present study addresses this gap and developed ternary blend HVFA concrete mixtures of up to $80 \%$ of cement replacement using low-calcium Class F fly ash and hydrated lime. The research data presented herein will contribute to the literature and will elucidate the reaction mechanism and strength development.

\section{Materials used}

\section{EXPERIMENTAL PROCEDURE}

Commercially available high-early-strength portland cement (ASTM Type III cement ${ }^{30}$ ) from a commercial supplier, low-calcium Class F fly ash (FA) conforming to AS $3582.1^{31}$ obtained from a power station in Australia, and hydrated lime conforming to AS $1672.1^{32}$ obtained from a commercial supplier were used to manufacture HVFA- 65 and HVFA- 80 concretes. The chemical composition of PC, fly ash, and hydrated lime (HL), as determined by X-ray fluorescence analysis, is shown in Table 1 . The mean particle size of fly ash was $20 \mu \mathrm{m}(0.000787 \mathrm{in}$.) and passing at $45 \mu \mathrm{m}(0.00197 \mathrm{in}$.) sieve was $87 \%$. The fly ash contained $62.5 \%$ of reactive amorphous phase material with non-reactive quartz (15.8\%) and mullite (19.2\%) as the crystalline phases, as quantified by $\mathrm{X}$-ray diffraction analysis. The hydrated lime consisted of $91 \%$ of calcium hydroxide. Both coarse and fine aggregate were prepared in accordance with AS 1141.5. ${ }^{33}$ The fine aggregate was river sand in dry condition with a specific gravity of 2.6 , water absorption of $0.85 \%$, and a fineness modulus of 2.9 . The coarse aggregate was crushed granite aggregate $(10 \mathrm{~mm}$ [0.394 in.] in size) with a specific gravity of 2.65 and water absorption of $1.74 \%$. The coarse aggregate used in concrete was in saturated surface-dry condition to prevent water absorption from the concrete mixture. 


\section{Mixture design}

To calculate the quantity of lime required for the 28-day pozzolanic reaction, the pozzolanic index $(\mathrm{PI})$ - a measure of the degree of fly ash reactivity with $\mathrm{Ca}(\mathrm{OH})_{2}$ and water in concrete-was determined. The mixture design was prepared as specified by ASTM C $618^{34}$ and ASTM C $311^{35}$ with water/binder ratio of 0.484 and is shown in Table 2 . Complete cement hydration is assumed at 28 days and the lime produced by hydration is assumed to be $25 \% .^{36}$ The equations provided in Table $3^{36}$ were used to calculate PI and, thus, calculate the percentage of lime required for the HVFA-65 and HVFA-80 concrete mixtures (Table 4).

The HVFA-65 and HVFA- 80 mixture proportions used are summarized in Table 5. The ratio of the components, cement, sand, coarse aggregates, and mixing water was calculated based on the absolute volume method. ${ }^{37} \mathrm{It}$ is noted

Table 2-Mortar mixture proportions, $\mathrm{kg} / \mathrm{m}^{3}\left(\mathrm{lb} / \mathrm{ft}^{3}\right)$

\begin{tabular}{c|c|c|c|c|c}
\hline $\begin{array}{c}\text { Mixture } \\
\text { notation }\end{array}$ & PC & FA & Sand & Water & 28-day strength \\
\hline $100 \mathrm{PC}$ & 500 & - & 1375 & 242 & $F_{c}=45.0 \mathrm{MPa}(6.5 \mathrm{ksi})$ \\
\hline$[80 \mathrm{PC}+20 \mathrm{FA}]$ & 400 & 100 & 1375 & 242 & $F_{c a}=39.9 \mathrm{MPa}(5.8 \mathrm{ksi})$ \\
\hline
\end{tabular}

Note: $F_{c}$ is strength of $100 \mathrm{PC}$ mortar and $F_{c a}$ is strength of $[80 \mathrm{PC}+20 \mathrm{FA}]$ mortar. that the initially calculated hydrated lime percentage, based on the PI in Table 4, is dependent on the strength activity index of the mortar mixture (that is, 28-day compressive strength of $100 \mathrm{PC} /[80 \mathrm{PC}+20 \mathrm{FA}])$. However, the present study is focused on optimizing the concrete mixture design and, thus, the hydrated lime percentage was varied based on the initially calculated hydrated lime percentage: from 8 to 15.5 and 13 to 20.5 for HVFA- 65 and HVFA- 80 concretes, respectively. The total binder content was fixed to $450 \mathrm{~kg} / \mathrm{m}^{3}$ $\left(28.1 \mathrm{lb} / \mathrm{ft}^{3}\right)$, the fly ash quantity in each mixture was adjusted based on hydrated lime percentage, maintaining the cement content at $35 \%$ and $20 \%$, respectively, and the combined fly ash and hydrated lime at $65 \%$ and $80 \%$, respectively. The water-binder ratio $(w / b)$ was kept at 0.3 , and a high earlystrength high-range water-reducing admixture (HRWRA), in liquid form, was used together with tap water to maintain the workability within the range of 55 to $65 \mathrm{~mm}$ (2.17 to 2.56 in.).

\section{Sample preparation}

The mixing of concrete was carried out using a $120 \mathrm{~L}$ $\left(4.238 \mathrm{ft}^{3}\right)$ concrete mixer. The dry materials (PC, fly ash, hydrated lime, sand, and coarse aggregates) were mixed

Table 3-Pozzolanic index (PI) calculations



Table 4-Lime requirement calculations (based on $\mathrm{PI}=\mathbf{0 . 1 4}$ )

\begin{tabular}{|c|c|c|c|}
\hline Definition & Formulas & HVFA-65 & HVFA- 80 \\
\hline Weight of fly ash & $P_{p}$ & $256.5 \mathrm{~kg} / \mathrm{m}^{3}$ & $301 \mathrm{~kg} / \mathrm{m}^{3}$ \\
\hline Hydration constant & $H_{x}=(0.914 w / c) /(w / c+0.17)$ & 0.763 & 0.821 \\
\hline Weight of free lime available & $0.25 \times P_{c} \times H_{x}$ & $30.04 \mathrm{~kg}$ & $18.47 \mathrm{~kg}$ \\
\hline Weight of extra lime required & {$\left[1.85 \times \mathrm{PI} \times P_{p}\right]-\left[0.25 \times P_{c} \times H_{x}\right]$} & $36 \mathrm{~kg}$ & $59 \mathrm{~kg}$ \\
\hline Required extra lime percentage & {$\left[\left(1.85 \times \mathrm{PI} \times P_{p}\right)-\left(0.25 \times P_{c} \times H_{x}\right)\right] / Q \times 100$} & $8 \%$ & $13 \%$ \\
\hline
\end{tabular}

Notes: $1 \mathrm{~kg} / \mathrm{m}^{3}=0.062 \mathrm{lb} / \mathrm{ft}^{3} ; 1 \mathrm{~kg}=2.2 \mathrm{lb}$. 
Table 5-Mixture designs for HVFA concrete

\begin{tabular}{c|c|c|c|c|c|c|c|c|c}
\hline \multirow{2}{*}{ Mixture notation } & \multicolumn{2}{|c|}{ Binder, $\%$} & \multicolumn{5}{c}{ Mixture proportions, $\mathrm{kg} / \mathrm{m}^{3}$} \\
\cline { 2 - 25 } & PC & FA & HL & PC & FA & HL & Sand & Aggregate & Water \\
\hline $100 \mathrm{PC}^{*}$ & 100 & - & - & 450 & - & - & 644 & 1218 & 135 \\
\hline $35 \mathrm{PC}+65 \mathrm{FA}^{*}$ & 35 & 65 & - & 157.5 & 292.5 & - & 604 & 1144 & 135 \\
\hline $35 \mathrm{PC}+57 \mathrm{FA}+8 \mathrm{HL}^{*}$ & 35 & 57 & 8 & 157.5 & 256.5 & 36 & 602 & 1140 & 135 \\
\hline $35 \mathrm{PC}+54.5 \mathrm{FA}+10.5 \mathrm{HL}^{*}$ & 35 & 54.5 & 10.5 & 157.5 & 245.25 & 47.25 & 602 & 1139 & 135 \\
\hline $35 \mathrm{PC}+52 \mathrm{FA}+13 \mathrm{HL}^{*}$ & 35 & 52 & 13 & 157.5 & 234 & 58.5 & 601 & 1137 & 135 \\
\hline $35 \mathrm{PC}+49.5 \mathrm{FA}+15.5 \mathrm{HL}^{*}$ & 35 & 49.5 & 15.5 & 157.5 & 222.75 & 69.75 & 600 & 1136 & 135 \\
\hline $20 \mathrm{PC}+80 \mathrm{FA}^{\dagger}$ & 20 & 80 & - & 90 & 360 & - & 595 & 1126 & 135 \\
\hline $20 \mathrm{PC}+67 \mathrm{FA}+13 \mathrm{HL}^{\dagger}$ & 20 & 67 & 13 & 90 & 301.5 & 58.5 & 592 & 1120 & 135 \\
\hline $20 \mathrm{PC}+64.5 \mathrm{FA}+15.5 \mathrm{HL}^{\dagger}$ & 20 & 64.5 & 15.5 & 90 & 290.25 & 69.75 & 591 & 1119 & 135 \\
\hline $20 \mathrm{PC}+62 \mathrm{FA}+18 \mathrm{HL}^{\dagger}$ & 20 & 62 & 18 & 90 & 279 & 81 & 591 & 1118 & 135 \\
\hline $20 \mathrm{PC}+59.5 \mathrm{FA}+20.5 \mathrm{HL}^{\dagger}$ & 20 & 59.5 & 20.5 & 90 & 267.75 & 92.25 & 590 & 1117 & 135 \\
\hline
\end{tabular}

"HVFA-65 concrete mixtures.

tHVFA-80 concrete mixtures.

Notes: $1 \mathrm{~kg} / \mathrm{m}^{3}=0.062 \mathrm{lb} / \mathrm{ft}^{3}$

first for 4 minutes. Water and HRWRA were added to the dry mixture and mixed continuously for another 8 minutes until the mixture was glossy and well combined. A slump test was conducted in accordance with Australian standard AS 1012.3.1 $1^{38}$ to ensure the concretes achieved the required workability. Immediately after mixing, the concrete mixture was poured into steel cylinder molds and compacted using a vibration table to remove air bubbles. All concrete specimens were demolded 1 day after casting and then cured in a lime-saturated water tank at $23^{\circ} \mathrm{C}\left(73.4^{\circ} \mathrm{F}\right)$ until being tested for compressive strengths.

The corresponding paste samples for X-ray diffraction (XRD), thermogravimetric analysis (TGA), and scanning electron microscopy (SEM) testing were prepared following the same mixture proportioning as the optimized HVFA-65 and HVFA- 80 concrete samples except that the sand and coarse aggregates are excluded. For the XRD and TGA tests, the paste samples were crushed and ground into fine particles and then filtered using $53 \mu \mathrm{m}$ sieve to obtain the required powder samples for testing at 3,7 , and 28 days.

\section{Testing}

Compressive strength testing was performed at 3, 7, 28, and 90 days using an MTS machine with a loading rate of $20 \mathrm{MPa} / \mathrm{min}(2.9 \mathrm{ksi} / \mathrm{min})$ according to AS 1012.9. ${ }^{39}$ The reported compressive strength values at a specific age are an average of four samples for each mixture.

The XRD data was obtained using a wide-angle X-ray diffractometer with copper anode at $40 \mathrm{kV}$ and $35 \mathrm{~mA}$. The TGA test was performed using a TGA machine under $\mathrm{N}_{2}$ atmosphere. The 5 to $12 \mathrm{mg}\left(1.1 \times 10^{-5}\right.$ to $\left.2.65 \times 10^{-5} \mathrm{lb}\right)$ of each powder sample was placed into the platinum crucible subject to a heating rate of $10^{\circ} \mathrm{C} / \mathrm{min}\left(18^{\circ} \mathrm{F} / \mathrm{min}\right)$, from 35 to $860^{\circ} \mathrm{C}\left(95\right.$ to $\left.1580^{\circ} \mathrm{F}\right)$. The percentage of mass loss due to decomposition with the increase of temperature was observed.

The heat of hydration of paste samples at a constant temperature of $23^{\circ} \mathrm{C}\left(73.4^{\circ} \mathrm{F}\right)$ were measured using an eight- channel standard volume calorimeter. Prior to mixing the paste, the cement, fly ash, and water were all kept at the room temperature for 24 hours to achieve a constant room temperature of $23^{\circ} \mathrm{C}\left(73.4^{\circ} \mathrm{F}\right)$ for all materials. Wooden sticks were used to manually mix the samples. Immediately after mixing, the samples were injected into $20 \mathrm{~mL}$ glass ampoules that were then placed in the calorimeter for 72 hours. The heat flow and cumulative heat over time for the samples were recorded as the isothermal calorimetry data. The data for each sample were normalized with respect to the total mass of its cementitious material so that different samples can be compared.

The setting times of pastes were tested using an automatic Vicat apparatus according to ASTM C191. During the test, a 1 $\mathrm{mm}$ (0.039 in.) Vicat needle settled into a paste sample every 15 minutes. The initial setting time was determined as the time between the moment when cement and water were first in contact and the time when the penetration of Vicat needle into the paste is $25 \mathrm{~mm}$ (0.984 in.). The final setting time was obtained to be the time elapsed between the time when water was first in contact with cement and the time when visible penetration of needle into the paste is not visible.

The microstructure was observed using scanning electron microscopy (SEM) imaging employing backscatter electron detector with $15 \mathrm{eV}$ of energy. The elemental analysis and chemistry of specific mixture were examined using an energy-dispersive X-ray spectroscope (EDS) attached to the SEM apparatus. The paste samples were cut using a diamond saw to a size of $15 \mathrm{~mm}$ (0.59 in.) in height and $25 \mathrm{~mm}(0.984 \mathrm{in}$.) in diameter and then carbon-coated and mounted on the SEM sample stage with conductive, doublesided carbon tape.

\section{Strength development}

\section{RESULTS AND DISCUSSION}

The results of the compressive strength tests are reported as the average of four specimens for each mixture at 3, 7, 28, and 90 days, as shown in Fig. 1 for HVFA-65 and Fig. 2 for 


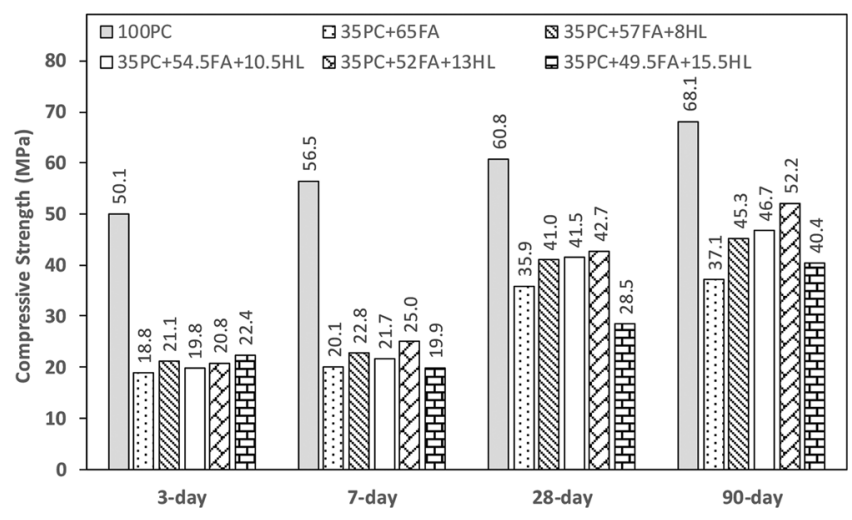

Fig. 1-Compressive strength development of HVFA-65 concrete. (Note: $1 \mathrm{MPa}=0.145 \mathrm{ksi}$.)

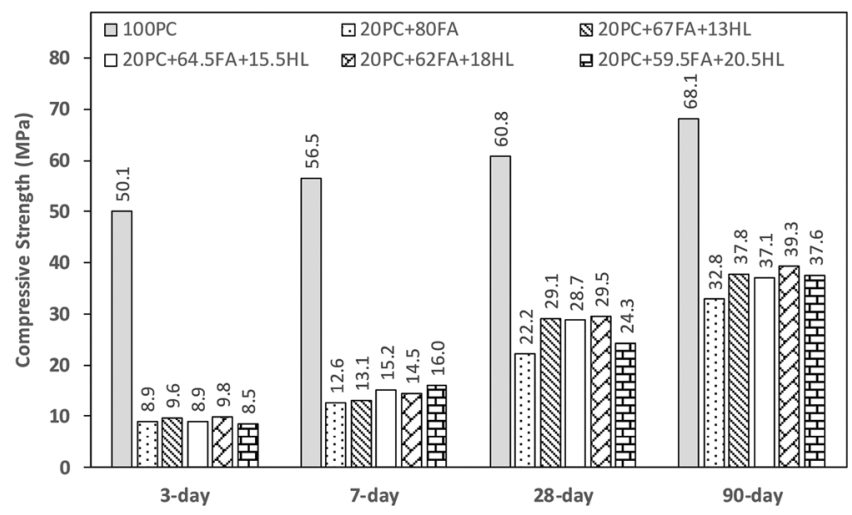

Fig. 2-Compressive strength development of HVFA-80 concrete. (Note: $1 \mathrm{MPa}=0.145 \mathrm{ksi}$.)

HVFA-80 concrete. Initially, both HVFA concrete mixtures were tested at the calculated hydrated lime percentage required (Table 4). Additional testing was then undertaken in $2.5 \%$ hydrated lime increments (Table 5) to determine the optimum mixture design. The compressive strength values were found to increase with an increase of hydrated lime percentage up to $13 \%$ and $18 \%$ for HVFA- 65 and HVFA- 80 concretes, respectively. A decrease in strength was subsequently noted for further addition of hydrated lime. The [35PC+52FA+13HL] concrete mixture had the highest compressive strength at 28 days for HVFA-65 concrete, whereas the $[20 \mathrm{PC}+62 \mathrm{FA}+18 \mathrm{HL}]$ concrete mixture gave the optimum 28-day strength for HVFA- 80 concrete. These mixture proportions were identified as the optimum mixture design for the specific HVFA concrete and used for the investigation of the reaction kinetics and microstructure development. There is an optimum hydrated lime content for specific HVFA concrete mixture. It is hypothesized that adding additional lime to the optimum leads to an increase in the exothermic process releasing additional heat during $\mathrm{Ca}(\mathrm{OH})_{2}$ formation. This causes internal expansion in the hydrated gel matrix and generates microcracks, which results in the strength reduction observed.

Both HVFA concretes displayed considerably lower compressive strength than the PC concrete at all ages. The compressive strength of the optimum HVFA-65 concrete increased from 20.8 to $52.2 \mathrm{MPa}$ (3.0 to $7.6 \mathrm{ksi}$ ), the optimum HVFA- 80 concrete from 9.8 to $39.3 \mathrm{MPa}$ (1.4 to $5.7 \mathrm{ksi}$ ),
Table 6-Strength activity index, \%

\begin{tabular}{c|c|c}
\hline Duration & HVFA-65 & HVFA-80 \\
\hline 3 days & 41.6 & 19.6 \\
\hline 7 days & 44.2 & 25.7 \\
\hline 28 days & 70.3 & 46.9 \\
\hline 90 days & 76.5 & 57.7 \\
\hline
\end{tabular}

and the PC concrete increased from 50.1 to $68.1 \mathrm{MPa}$ (7.3 to $9.9 \mathrm{ksi}$ ) over the period from 3 to 90 days. However, the HVFA-65 concrete demonstrated a twofold strength increase while HVFA- 80 concrete had a threefold strength gain between 3 and 28 days. The calculated strength activity index (HVFA strength/PC strength) varied between 41.6 and $76.5 \%$ and 19.6 and $57.7 \%$ for HVFA- 65 and HVFA- 80 concrete, respectively (Table 6). This indicates that the hydration continues in the HVFA concretes up to 90 days, and, as would be anticipated due to the pozzolanic reaction of the fly ash with the hydrated lime, that the percentage of strength development is significantly larger than in PC concrete over this period.

\section{Isothermal calorimetry}

The variation of normalized heat flow of 100PC, optimized HVFA-65, and optimized HVFA- 80 paste mixtures up to 72 hours is illustrated in Fig. 3(a) and 3(b). The 100PC paste had the greatest heat flow over time compared with the HVFA pastes. It was noted that with the increase of cement replacement with the combination of fly ash and hydrated lime, the overall height of the normalized heat flow curve decreased, indicating a lower rate of hydration for HVFA pastes than 100PC.

At the time of mixing, hydration occurs rapidly, identified as the first peak in the normalized heat flow curve. This is principally due to the hydration of $\mathrm{C}_{3} \mathrm{~A}$ and $\mathrm{C}_{4} \mathrm{AF}$ phases (Fig. 3(b)). ${ }^{40}$ It was noted that this first peak appears earlier for HVFA pastes than for 100PC. Moreover, the duration of the dormant period, occurring after the first peak, is shortened for both HVFA- 65 and HVFA- 80 paste. This observation indicates that the hydration of $\mathrm{C}_{3} \mathrm{~A}$ and $\mathrm{C}_{4} \mathrm{AF}$ phases for HVFA pastes occurs earlier than for 100PC paste. Further, the hydration of these phases was faster with the increase of fly ash percentage in paste. It is noted that the hydration peaks are expected to start primarily with silicate phases $\left(\mathrm{C}_{3} \mathrm{~S}\right.$ and $\left.\mathrm{C}_{2} \mathrm{~S}\right)$ followed by aluminate phases $\left(\mathrm{C}_{3} \mathrm{~A}\right.$ and $\left.\mathrm{C}_{4} \mathrm{AF}\right)$. The dilution of cement slows down the hydration of the silicate phases, resulting in a lower primary peak compared to the plain OPC. However, with fly ash inclusion, the hydration of aluminate phases becomes more dominant.

The second peak coming after the dormant period is associated with the hydration of $\mathrm{C}_{3} \mathrm{~S}$ and the production of the main hydrates $\mathrm{C}-\mathrm{S}-\mathrm{H}$ and $\mathrm{CH}$. Setting also occurs during this period. Figure 3(a) shows that with the increase of fly ash and hydrated lime in the paste, the second peak of the heat flow curve shifted to the left. This is contrary to the heat flow curves of binary cement paste with fly ash observed in previous research. ${ }^{41,42}$ For PC pastes with fly ash as the only supplementary cementitious material (SCM), the heat flow curve usually shifts to the right, with larger fly ash 


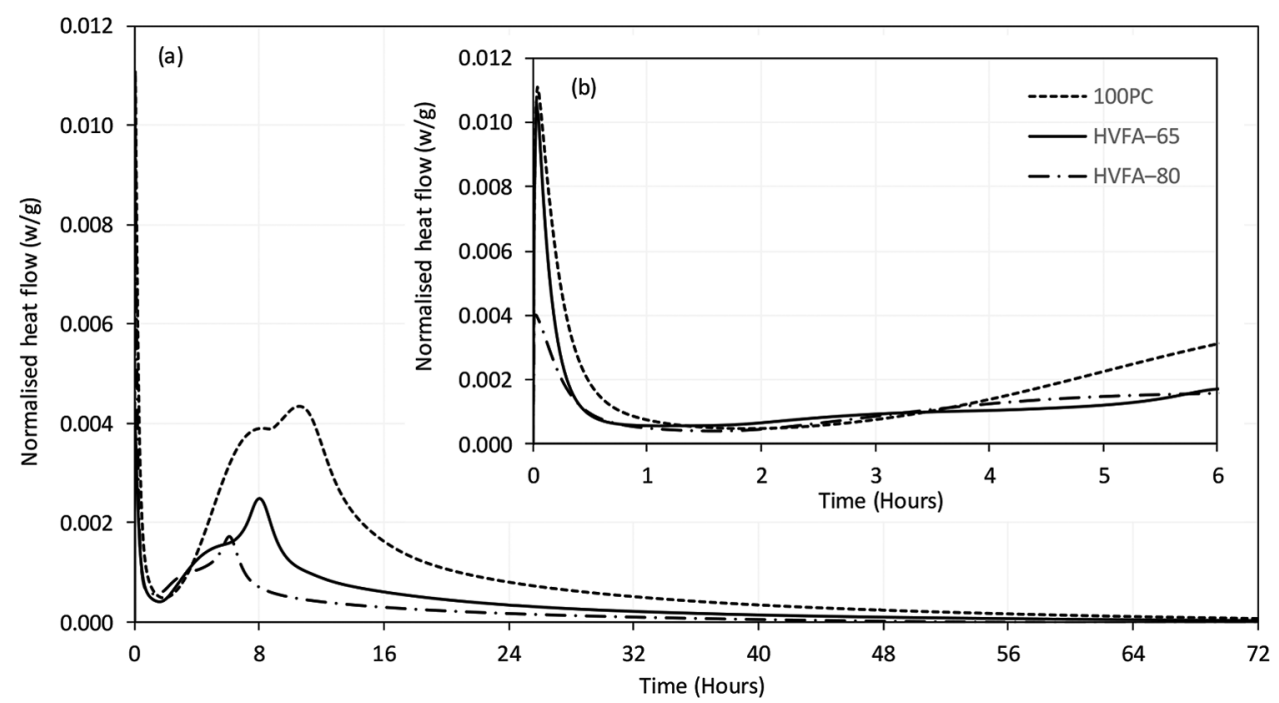

Fig. 3-Normalized heat flow curves for 100PC, optimized HVFA-65, and optimized HVFA-80 pastes.

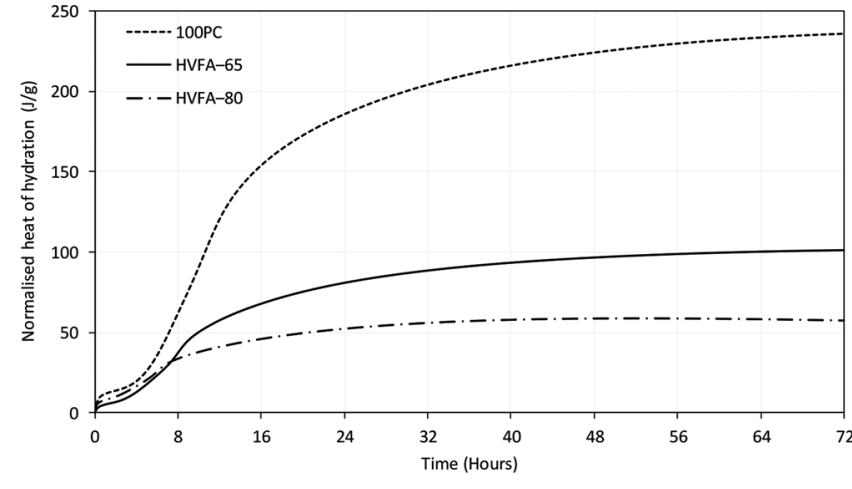

Fig. 4-Normalized cumulative heat curves for 100PC, optimized HVFA-65, and optimized HVFA-80 pastes.

dosages contributing to a larger shift. ${ }^{41,42}$ The reason for the accelerated advent of the second peak in the heat flow curves of HVFA- 65 and HVFA- 80 pastes is attributed to the addition of hydrated lime. It has been reported that the presence of alkalis can speed up the appearance of the second peak, due to earlier formation of $\mathrm{C}_{3} \mathrm{~S}$ hydrate. ${ }^{40}$ The shape of the second peak is also changed for both HVFA pastes. In the 100PC paste, the second peak of the heat flow curve is quite conspicuous. However, in HVFA-65 and HVFA-80 paste, the second peak is less prominent compared to the 100PC sample. HVFA-80 paste also has a smaller second peak compared with the HVFA-65 paste. This would indicate that the increase of FA and hydrated lime dosage results in less-intensive hydration of $\mathrm{C}_{3} \mathrm{~S}$.

The third peak, quickly following the second peak, is due to renewed hydration of $\mathrm{C}_{3} \mathrm{~A}$ and $\mathrm{C}_{4} \mathrm{AF}$ phases. It can be seen that the HVFA- 80 paste had the earliest occurrence of the third peak and 100PC paste had the latest. As mentioned in previous studies, the entire heat flow curve would shift to the right with an increase of fly ash dosage. Thus, the occurrence of the third peak would be expected to be delayed. In this study, the increase of fly ash content accelerates the advent of the third peak instead. This could also be due to the adding of hydrated lime causing the renewed hydration reaction of $\mathrm{C}_{3} \mathrm{~A}$ and $\mathrm{C}_{4} \mathrm{AF}$ phases to occur earlier.

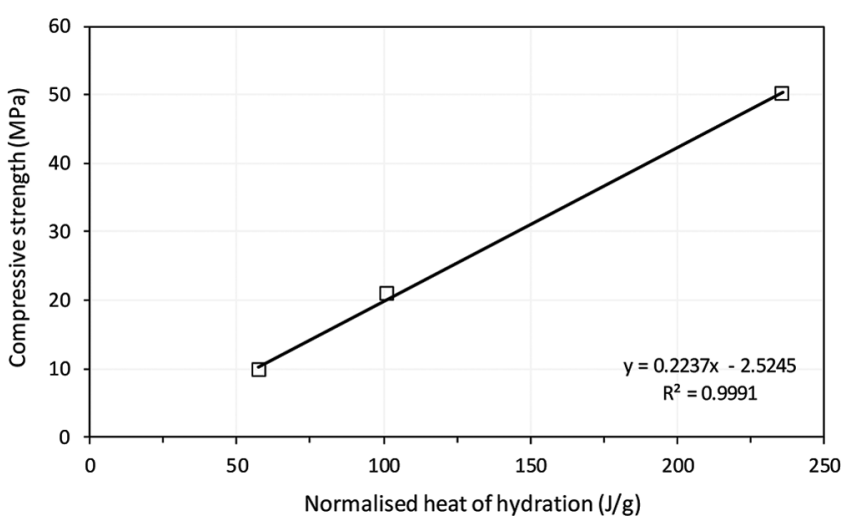

Fig. 5-Correlation between compressive strength and normalized cumulative heat at age of 3 days. (Note: $1 \mathrm{MPa}$ $=0.145 \mathrm{ksi}$.)

From the cumulative heat of hydration curves in Fig. 4, the heat development decreases with the increase of fly ash and hydrated lime dosages. This is as expected, as the compressive strength testing in 100PC, HVFA-65, and HVFA-80 concretes shows that the compressive strength was reduced with increasing cement replacement. Comparing the cumulative heat produced at 72 hours and compressive strength at the age of 3 days, as shown in Fig. 5, a good correlation can be observed. Previous research has also indicated that the heat of hydration is linearly correlated with the compressive strength and, thus, is a good indicator for the prediction of strength development. ${ }^{43}$

\section{Thermogravimetric analysis (TGA)}

The percentage of mass loss of 100PC and optimized HVFA paste samples due to decomposition with temperature are presented as TGA curves in Fig. 6(a) to 6(c). The cement hydrates decompose primarily in three stages, and this study follows the method prosed by Deboucha et al. ${ }^{44}$ Hence, the first stage, the weight loss of sample between 25 and $400^{\circ} \mathrm{C}$ ( 77 and $752^{\circ} \mathrm{F}$ ) is associated with evaporation of free water ( 25 to $105^{\circ} \mathrm{C}$ [ 77 to $\left.221^{\circ} \mathrm{F}\right]$ ) and the dehydration reaction (105 to $400^{\circ} \mathrm{C}$ [221 to $\left.752^{\circ} \mathrm{F}\right]$ ). During the second stage 

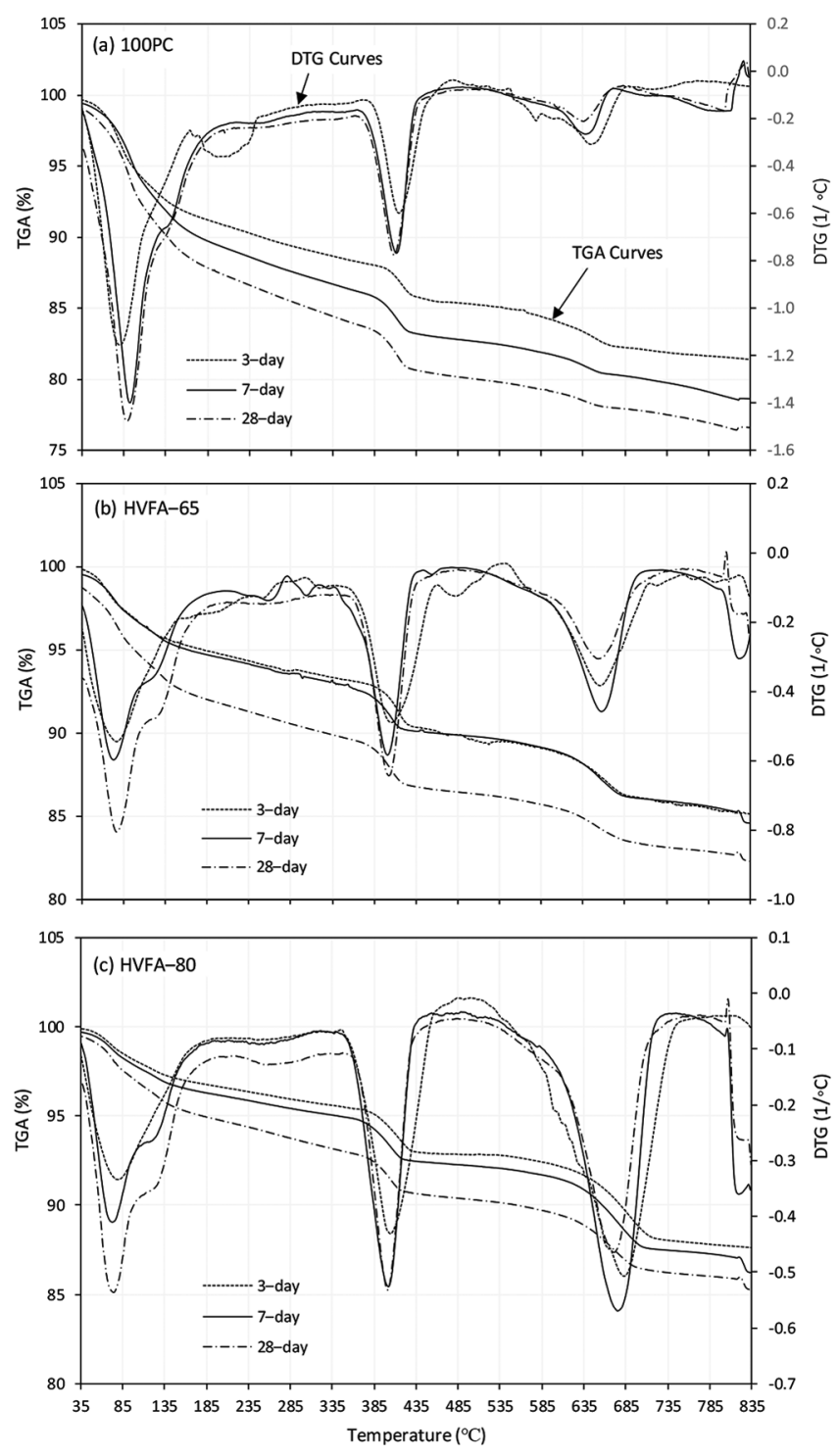

Fig. 6-TGA and DTG curves for 100PC, optimized HVFA65 , and optimized HVFA-80 pastes. (Note: $1^{\circ} \mathrm{C}=33.8^{\circ} \mathrm{F}$.)

between 400 and $600^{\circ} \mathrm{C}\left(752\right.$ and $\left.1112^{\circ} \mathrm{F}\right)$, the weight loss is due to the dihydroxylation of portlandite ( $\mathrm{Ldx})$. The third stage between 600 and $900^{\circ} \mathrm{C}\left(1112\right.$ and $\left.1652^{\circ} \mathrm{F}\right)$ represents decarbonation of $\mathrm{CaCO}_{3}$ ( $\mathrm{Ldc}$ ). The actual temperature ranges are subject to minor changes referring to the first derivative of TGA curves, DTG. The amount of portlandite or calcium hydroxide $(\mathrm{CH})$ in pastes at specific age is calculated using Eq. (1)

$$
\mathrm{CH} \%=4.11 \mathrm{Ldx}+1.68 \mathrm{Ldc}
$$

It is noted that the weight loss of all pastes increases between 3 and 28 days, indicating the increase of cement hydrates over time. There are three major drops in the DTG curves for all the mixturees representing the mass loss due to dehydration ( $\mathrm{Ldh}$ ), dihydroxylation ( $\mathrm{Ldx}$ ), and decarbonation ( $\mathrm{Ldc}$ ), respectively. The values of $\mathrm{Ldh}, \mathrm{Ldx}$, and Ldc, calculated from the TGA and DTG curves, are listed in Table 7. The $\mathrm{CH}$ quantity in the pastes are calculated and presented in Fig. 7. Both HVFA specimens showed a

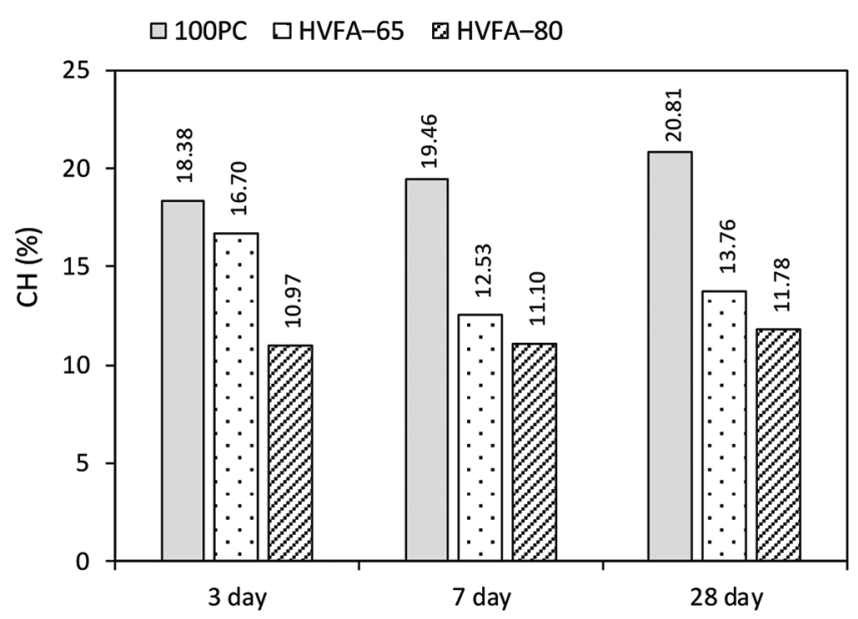

Fig. 7-Percentages of $\mathrm{CH}$ in 100PC, optimized HVFA-65, and optimized HVFA-80 pastes.

Table 7-Results from TGA and DTG curves

\begin{tabular}{c|c|c|c|c|c|c}
\hline \multirow{2}{*}{ Specimen } & \multirow{2}{*}{$\begin{array}{c}\text { Curing, } \\
\text { days }\end{array}$} & \multicolumn{5}{|c}{ Percentage of each compound, \% } \\
\cline { 3 - 7 } & 3 & 6.168 & 3.97 & 3.698 & 2.473 & 18.375 \\
\hline \multirow{3}{*}{100 PC } & 7 & 8.054 & 4.317 & 3.536 & 2.511 & 19.464 \\
\cline { 2 - 7 } & 28 & 8.794 & 4.53 & 3.416 & 2.114 & 20.807 \\
\hline & 3 & 4.262 & 3.4 & 4.968 & 3.346 & 16.698 \\
\hline \multirow{3}{*}{ HVFA-65 } & 7 & 5.3 & 2.34 & 5.049 & 3.316 & 12.528 \\
\cline { 2 - 7 } & 28 & 6.467 & 2.669 & 4.285 & 2.627 & 13.755 \\
\hline \multirow{4}{*}{ HVFA-80 } & 3 & 3.463 & 2.26 & 5.432 & 4.431 & 10.97 \\
\cline { 2 - 7 } & 7 & 4.138 & 1.989 & 5.983 & 4.243 & 11.101 \\
\cline { 2 - 7 } & 28 & 5.117 & 2.188 & 5.168 & 3.507 & 11.783 \\
\hline
\end{tabular}

lower $\mathrm{CH}$ percentage at all ages compared to $100 \mathrm{PC}$ paste. For $100 \mathrm{PC}$ paste, $\mathrm{CH}$ increased from 3 to 28 days as $\mathrm{CH}$ was released from hydration of $\mathrm{PC}$ over time. However, for both HVFA-65 and HVFA- 80 pastes, the percentage of $\mathrm{CH}$ in the pastes at 7 and 28 days declined compared to 3 days. This could be due to the pozzolanic and hydration of fly ash consuming the $\mathrm{CH}$ produced from $\mathrm{PC}$ hydration. Low-calcium fly ash can react up to a week after the time of mixing, as the fly ash can only be activated when there is adequate alkalinity accumulated in the pore solution by PC hydration. ${ }^{40}$ In HVFA- 65 and HVFA- 80 pastes, the $\mathrm{CH}$ was already consumed at 7 days. The reason could be that the added hydrated lime in the mixtures prior to the hydration of the cement was sufficient to initiate the hydration of fly ash at this earlier age, as reflected in the earlier occurrence of the peaks in the heat flow curve.

It can also be observed that the CH quantity in HVFA-65 paste at 7 days was $12.5 \%$, less than the added hydrated lime before hydration, which is $13 \%$. This indicates that in the HVFA-65 paste, fly ash at 7 days consumed not only the $\mathrm{CH}$ produced from $\mathrm{PC}$ hydration but also the added hydrated lime in the paste. For HVFA- 65 paste at 28 days, the $\mathrm{CH}$ content increase beyond $13 \%$. This could be due to the release of $\mathrm{CH}$ from $\mathrm{PC}$ hydration exceeding the consumption of $\mathrm{CH}$ by fly ash reaction. For HVFA- 80 paste, the 
(a) 3-day

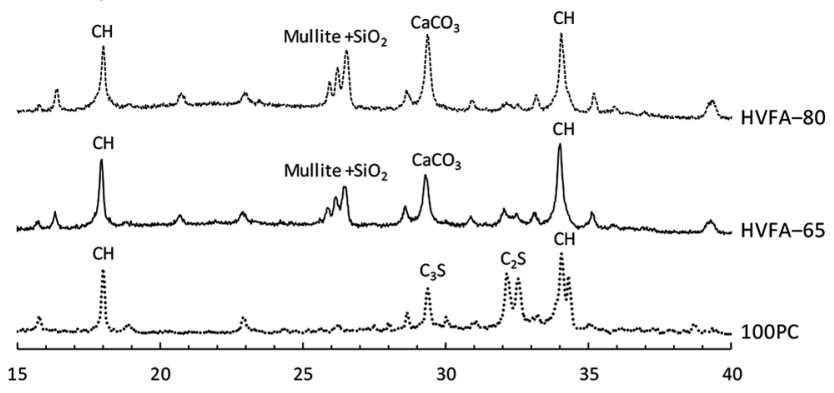

(b) 7-day



(c) 28-day
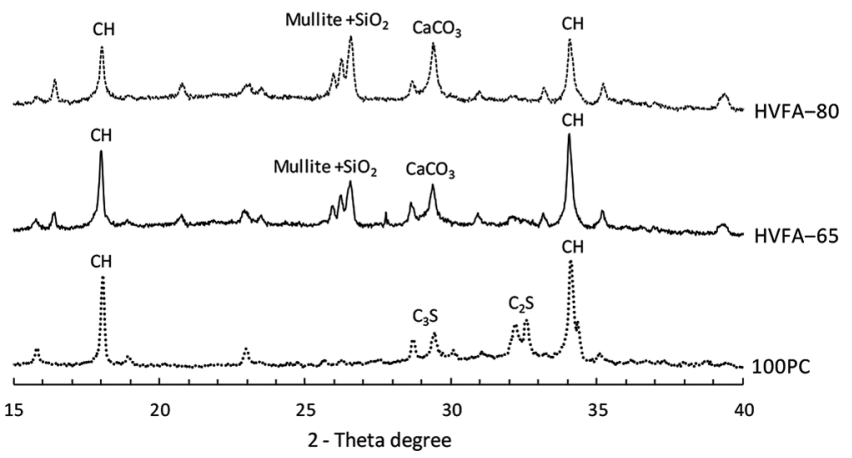

Fig. 8-Diffractograms for 100PC, optimized HVFA-65, and optimized HVFA-80 pastes.

amount of $\mathrm{CH}$ were $11.1 \%$ and $11.8 \%$ at both 7 days and 28 days, less than the added hydrated lime before hydration, which is $18 \%$. This shows that for HVFA- 80 paste, fly ash consumed the added hydrated lime at both 7 and 28 days. Thus, for both HVFA- 65 and HVFA- 80 pastes, the added hydrated lime contributes to the pozzolanic and hydration of fly ash at ages as early as 7 days by participating in the reaction with fly ash.

\section{XRD analysis}

The variation of XRD patterns of $100 \mathrm{PC}$, optimized HVFA- 65 and optimized HVFA- 80 paste between 3 and 28 days are shown in Fig. 8(a) to 8(c). From 3 to 28 days, the peaks representing $\mathrm{C}_{3} \mathrm{~S}$ and $\mathrm{C}_{2} \mathrm{~S}$ phases in $100 \mathrm{PC}$ pastes reduce in size, indicating the consumption of $\mathrm{C}_{3} \mathrm{~S}$ and $\mathrm{C}_{2} \mathrm{~S}$ due to $\mathrm{PC}$ hydration over time. In the XRD patterns of both HVFA- 65 and HVFA- 80 pastes, there are two peaks at 25.2 and 26 deg $2 \theta$ representing mullite and $\mathrm{SiO}_{2}$, respectively, which are not present in $100 \mathrm{PC}$ paste. As mullite and $\mathrm{SiO}_{2}$ are major crystalline phases contained in fly ash, they can serve as indications of fly ash reaction in the pastes. In the diffractograms of HVFA-65 paste, the height and width of the peak representing $\mathrm{SiO}_{2}$ decreased between 3 to 28 days. The peak for $\mathrm{SiO}_{2}$ in the diffractograms of HVFA- 80 paste shows a similar trend. This also correlates with the TGA results, which indicate that the fly ash in both HVFA pastes has started to react by the age of 7 days. It can also be observed that $\mathrm{SiO}_{2}$ and mullite still remain in the HVFA-65 and HVFA- 80 pastes at 28 days. Thus, the fly ash in both HVFA pastes has not been completely consumed at the age of 28 days.

Comparing the peaks representing $\mathrm{CH}$ in the diffractograms, it can be seen that for $100 \mathrm{PC}$, the amount of $\mathrm{CH}$ in the paste increases from 3 to 28 days, as $\mathrm{CH}$ is produced constantly from PC hydration. The HVFA- 80 paste displayed a similar trend to $100 \mathrm{PC}$ with increasing $\mathrm{CH}$ content over time; however, the quantity of $\mathrm{CH}$ in the paste is significantly lower than 100PC. The HVFA-65 displayed contradictory behavior to 100PC: the $\mathrm{CH}$ content decreased from 3 to 7 days and increased from 7 to 28 days. It is hypothesized that the quantity of $\mathrm{CH}$ consumed by fly ash hydration in HVFA-65 is more than that produced from PC hydration in the period from 3 to 7 days. This resulted in the higher early-age strength development observed in HVFA-65 concrete compared to the HVFA- 80 concrete. These observations are consistent with the findings in TGA tests.

A peak representing $\mathrm{CaCO}_{3}$ appears at $29.42 \theta$ for both HVFA-65 and HVFA- 80 pastes but is not observed for 100PC paste. The HVFA- 80 paste has a higher $\mathrm{CaCO}_{3}$ content throughout compared to the HVFA- 65 paste. The $\mathrm{CaCO}_{3}$ produced is attributed to carbonation of $\mathrm{Ca}(\mathrm{OH})_{2}$. The presence of the $\mathrm{CaCO}_{3}$ in the diffractograms indicates that this carbonation occurs within 3 days in HVFA concrete and the quantity of $\mathrm{CaCO}_{3}$ increases as fly ash and hydrated lime content increases. It is also observed that for both HVFA- 65 and HVFA- 80 pastes, the quantity of $\mathrm{CaCO}_{3}$ decreased between 3 to 28 days. This is due to the pore water becoming saturated with carbon dioxide over time, leading to the formation of the more-soluble calcium bicarbonate.

\section{Setting time}

The initial setting time, defined as the time when paste first starts to loss its plasticity, of the 100PC, optimized HVFA-65 and optimized HVFA-80 pastes are 143.82, 150.99 , and 184.62 minutes, respectively. The 100PC paste had the shortest initial setting time, while the HVFA- 80 paste had the longest initial setting time. This indicates that, with an increase in fly ash content from $65 \%$ to $80 \%$, the time for pastes to initially lose plasticity increases as compared to $100 \%$ PC paste, even with the addition of hydrated lime. The final setting time correlates to the time required for a paste to loss its plasticity completely. The observed final setting time of 100PC, HVFA-65, and HVFA-80 pastes are 587.22, 459.22, and 427.22 minutes, respectively. It was noted that the 100PC had the longest final setting time whereas the HVFA- 80 had the shortest final setting time. This shows that, with the increase of fly ash dosage from $65 \%$ to $80 \%$ and hydrated lime dosage from $13 \%$ to $18 \%$, the time for pastes to completely lose their plasticity decreases.

These results would indicate that, while an increase in replacement by fly ash and hydrated lime increases the initial 

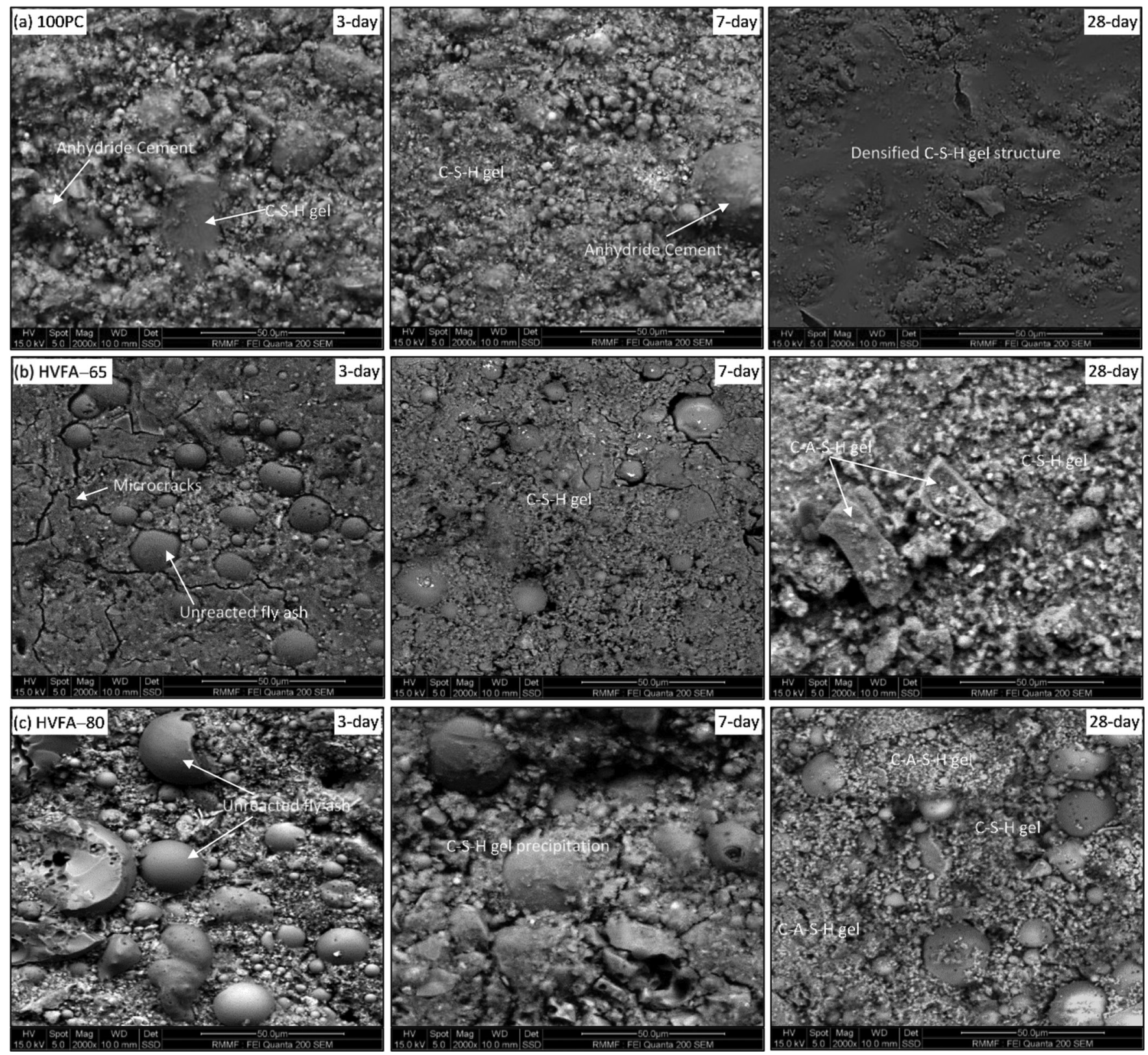

Fig. 9-Microstructure development of 100PC, optimized HVFA-65, and optimized HVFA-80 pastes.

setting time, it also actually reduces the final setting time. The increase in setting time can be attributed to the delay in activation due to the reducing in the PC content while the reduction in final setting time can be attributed to activation of the fly ash by the hydrated lime coupled with additional nucleation sites due to the increased hydrated lime content. This correlates with the isothermal calorimetry results. The second peak of the heat flow curve being associated with the final setting. The results show that the adding of hydrated lime can accelerate the setting time such that HVFA concrete with a higher fly ash dosage will set quicker than those with lower fly ash content.

\section{Microstructure}

Figure 9 shows the microstructure development observed in 100PC and optimized HVFA concretes between 3 and 28 days. The 100PC concrete has a well-compacted, uniform, dense pore structure at 28 days, which is consistent with the observed high compressive strength. It further showed a higher degree of hydration and concurrent C-S-H gel formation at 7 days, with only a few anhydride cement particles observed in the gel matrix. The HVFA-65 and HVFA- 80 concretes displayed a similar microstructure, being heterogeneous in nature, with an increased number of unreacted/ partially reacted fly ash spheres observed, in particular after 7 days. These materials are composites; hence, the strength of the unreacted fly ash particles, and the interface between them and C-S-H gel matrix, is expected to have a significant bearing on the overall strength of the material. ${ }^{45}$ The presence of extra void spaces and microcracks were also observed from the SEM micrographs of HVFA concretes as compared to 100PC concrete. It is noted that these microcracks are generated at the interface of the unreacted fly ash-gel phase and then extended through the bulk gel matrix. These observations would explain the lower strength of the two HVFA concretes compared to the 100PC concrete. 
On the other hand, additional calcium-aluminosilicatehydrate (C-A-S-H) is expected to be generated in the HVFA concretes which will coexist with $\mathrm{C}-\mathrm{S}-\mathrm{H}$ gel, providing an increase in density in the microstructure. The addition of hydrated calcium (lime) is also expected to accelerate hardening and dissolution by providing extra nucleation sites. This is suggested as the cause of the significant increase in compressive strength between 3 and 28 days in both HVFA concretes.

\section{SUMMARY AND CONCLUSIONS}

The following conclusions can be made from the research presented in this paper:

1. Two ternary blend high-volume fly ash concrete mixtures-HVFA-65 and HVFA-80 - were designed incorporating hydrated lime to activate the fly ash. Compressive strengths up to 53 and $40 \mathrm{MPa}$ were achieved at 90 days with HVFA-65 and HVFA-80 concrete, respectively.

2. Hydration of $\mathrm{C}_{3} \mathrm{~A}$ and $\mathrm{C}_{4} \mathrm{AF}$ phases in HVFA concretes occurs earlier than PC concrete. Further, hydration of these phases was accelerated by an increase of fly ash percentage in the concrete. On the other hand, the increase of fly ash and hydrated lime resulted in reduced hydration of the $\mathrm{C}_{3} \mathrm{~S}$ phase in the HVFA concretes.

3. The addition of hydrated lime stimulated the initial pozzolanic reaction and hydration of fly ash during the first 7 days in the HVFA concretes.

4. The $\mathrm{CH}$ content of HVFA-65 decreased between 3 to 7 days but increased from 7 to 28 days. This is due to the quantity of $\mathrm{CH}$ consumed by fly ash hydration in HVFA- 65 being more than that produced from PC hydration in the first 7 days. This resulted in higher early-age strength for HVFA-65 than HVFA-80 concrete.

5. In HVFA- 65 and HVFA- 80 concretes, the added hydrated lime contributes to the hydration of fly ash at ages as early as 7 days by participating in the reaction with fly ash.

6. The carbonation at early ages becomes more severe with the increase of fly ash and hydrated lime content in the HVFA concrete. The reduction of $\mathrm{CaCO}_{3}$ content between 3 and 28 days is attributed to the dissolution of $\mathrm{CaCO}_{3}$ in the pore water, the solubility increasing due to the formation of more the soluble calcium bicarbonate.

7. While initial setting time of HVFA concrete increases with an increase of fly ash content, the final setting time decreases. The activation of the fly ash by the hydrated lime and the additional nucleation sites created due to the increased hydrated lime content is the cause of the accelerated final setting time of HVFA concrete.

\section{AUTHOR BIOS}

Chamila Gunasekara is a Postdoctoral Research Fellow in the School of Engineering, RMIT University, Melbourne, Australia. His research interests include advanced construction materials and technologies, material characterization, and performance of geopolymer and high-volume fly ash concrete.

Zhiyuan Zhou is a PhD Student in the Department of Infrastructure Engineering, the University of Melbourne, Melbourne, Australia. Her research interests include performance of high-volume fly ash concrete and hydration and microstructure of concrete with supplementary cementitious materials.
Massoud Sofi is a Postdoctoral Research Fellow in the Department of Infrastructure Engineering, the University of Melbourne. His research interests include structural health monitoring in reinforced concrete structures, sustainability, advanced materials technology, and disaster management.

David W. Law is a Senior Lecturer in the School of Engineering, RMIT University. His research interests include the durability and performance of reinforced concrete structures, geopolymer concrete, electrochemical monitoring and protection, the use of sustainable materials, and material properties of concrete.

Sujeeva Setunge is a Professor and Deputy Dean of School of Engineering at RMIT University. Her research interests include concrete technology, geopolymer concrete, concrete structures, behavior, strengthening, creep, shrinkage, infrastructure management, and disaster resilience.

Priyan Mendis is a Professor in the Department of Infrastructure Engineering, the University of Melbourne. His research interests include fire behavior of structures, high-strength concrete, modeling and durability of infrastructure, new construction, and defense materials and nanotechnology in construction.

\section{ACKNOWLEDGMENTS}

The authors wish to acknowledge Boral Limited, Flyash Australia Pty Ltd, and Independent Cement \& Lime Pty Ltd for the supply of materials. The X-ray facility and Microscopy \& Microanalysis facility provided by RMIT University and the calorimetry tests conducted in Melbourne University are also acknowledged. This research was conducted by the Australian Research Council Industrial Transformation Research Hub for nanoscience-based construction material manufacturing (IH150100006) and funded by the Australian Government. The financial supports from the Australian Research Council's Discovery Early Career Researcher Grant (DE170100165, DE 2017 R1), Australian Postgraduate Award, and the University of Melbourne are also acknowledged. The authors declare that they have no conflict of interest.

\section{REFERENCES}

1. Long, G.; Gao, Y.; and Xie, Y., "Designing More Sustainable and Greener Self-Compacting Concrete," Construction and Building Materials, V. 84, 2015, pp. 301-306. doi: 10.1016/j.conbuildmat.2015.02.072

2. Gartner, E., "Industrially Interesting Approaches to $\mathrm{Low}-\mathrm{CO}_{2}$ Cements," Cement and Concrete Research, V. 34, No. 9, 2004, pp. 1489 1498. doi: 10.1016/j.cemconres.2004.01.021

3. Meyer, C., "The Greening of the Concrete Industry," Cement and Concrete Composites, V. 31, No. 8, 2009, pp. 601-605. doi: 10.1016/j. cemconcomp.2008.12.010

4. Chen, C.; Habert, G.; Bouzidi, Y.; and Jullien, A., "Environmental Impact of Cement Production: Detail of the Different Processes and Cement Plant Variability Evaluation," Journal of Cleaner Production, V. 18, No. 5, 2010, pp. 478-485. doi: 10.1016/j.jclepro.2009.12.014

5. Park, J. H.; Edraki, M.; Mulligan, D.; and Jang, H. S., "The Application of Coal Combustion By-Products in Mine Site Rehabilitation," Journal of Cleaner Production, V. 84, 2014, pp. 761-772. doi: 10.1016/j. jclepro.2014.01.049

6. Khale, D., and Chaudhary, R., "Mechanism of Geopolymerization and Factors Influencing its Development: A Review," Journal of Materials Science, V. 42, No. 3, 2007, pp. 729-746. doi: 10.1007/s10853-006-0401-4

7. Li, G., "Properties of High-Volume Fly Ash Concrete Incorporating Nano-SiO ${ }_{2}$," Cement and Concrete Research, V. 34, No. 6, 2004, pp. $1043-$ 1049. doi: 10.1016/j.cemconres.2003.11.013

8. Volz, J. S.; Se, P.; Arezoumandi, M.; Looney, T.; and Ortega, C., "HighVolume Fly Ash Concrete," Center for Transportation Infrastructure and Safety, Missouri S\&T, Rolla, MO, 2013.

9. Moffatt, E. G.; Thomas, M. D. A.; and Fahim, A., "Performance of High-Volume Fly Ash Concrete in Marine Environment," Cement and Concrete Research, V. 102, 2017, pp. 127-135. doi: 10.1016/j. cemconres.2017.09.008

10. Alaka, H. A., and Oyedele, L. O., "High Volume Fly Ash Concrete: The Practical Impact of Using Superabundant Dose of High Range Water Reducer," Journal of Building Engineering, V. 8, 2016, pp. 81-90. doi: 10.1016/j.jobe.2016.09.008

11. Malhotra, V. M., and Mehta, P. K., High-Performance, High-Volume Fly Ash Concrete: Materials, Mixture Proportioning, Properties, Construction Practice, and Case Histories, Supplementary Cementing Materials for Sustainable Development, Inc., Ottowa, ON, Canada, 2002, 101 pp.

12. Gunasekera, C.; Ling, X.; Setunge, S.; Law, D.; and Patnaikuni, I., "Performance of High-Volume Fly Ash Concrete Incorporating Lime 
Water," ACI Materials Journal, V. 115, No. 2, Mar. 2018, pp. 289-297. doi: $10.14359 / 51701238$

13. Wang, A.; Zhang, C.; and Sun, W., "Fly Ash Effects: I. The Morphological Effect of Fly Ash," Cement and Concrete Research, V. 33, No. 12, 2003, pp. 2023-2029. doi: 10.1016/S0008-8846(03)00217-5

14. Wang, A.; Zhang, C.; and Sun, W., "Fly Ash Effects: II. The Active Effect of Fly Ash," Cement and Concrete Research, V. 34, No. 11, 2004, pp. 2057-2060. doi: 10.1016/j.cemconres.2003.03.001

15. De la Varga, I.; Castro, J.; Bentz, D. P.; Zunino, F.; and Weiss, J., "Evaluating the Hydration of High-Volume Fly Ash Mixtures Using Chemically Inert Fillers," Construction and Building Materials, V. 161, 2018, pp. 221-228. doi: 10.1016/j.conbuildmat.2017.11.132

16. Liu, M.; Tan, H.; and He, X., "Effects of Nano- $\mathrm{SiO}_{2}$ on Early Strength and Microstructure of Steam-Cured High Volume Fly Ash Cement System," Construction and Building Materials, V. 194, 2019, pp. 350-359. doi: 10.1016/j.conbuildmat.2018.10.214

17. Malhotra, V. M.; Zhang, M.-H.; Read, P. H.; and Ryell, J., "LongTerm Mechanical Properties and Durability Characteristics of HighStrength/High-Performance Concrete Incorporating Supplementary Cementing Materials under Outdoor Exposure Conditions," ACI Materials Journal, V. 97, No. 5, Sept.-Oct. 2000, pp. 518-525.

18. Swamy, R.; Ali, S. A.; and Theodorakopoulos, D., "Early Strength Fly Ash Concrete for Structural Applications," ACI Journal Proceedings, V. 80, No. 5, Sept.-Oct. 1983, pp. 414-423.

19. Barbhuiya, S. A.; Gbagbo, J. K.; Russell, M. I.; and Basheer, P. A. M., "Properties of Fly Ash Concrete Modified with Hydrated Lime and Silica Fume," Construction and Building Materials, V. 23, No. 10, 2009, pp. 3233-3239. doi: 10.1016/j.conbuildmat.2009.06.001

20. Shafigh, P.; Nomeli, M. A.; Alengaram, U. J.; Mahmud, H. B.; and Jumaat, M. Z., "Engineering Properties of Lightweight Aggregate Concrete Containing Limestone Powder and High Volume Fly Ash," Journal of Cleaner Production, V. 135, 2016, pp. 148-157. doi: 10.1016/j. jclepro.2016.06.082

21. Babu, D. S.; Babu, K. G.; and Wee, T., "Properties of Lightweight Expanded Polystyrene Aggregate Concretes Containing Fly Ash," Cement and Concrete Research, V. 35, No. 6, 2005, pp. 1218-1223. doi: 10.1016/j. cemconres.2004.11.015

22. Kumar, B.; Tike, G.; and Nanda, P., "Evaluation of Properties of High-Volume Fly-Ash Concrete for Pavements," Journal of Materials in Civil Engineering, ASCE, V. 19, No. 10, 2007, pp. 906-911. doi: 10.1061/ (ASCE)0899-1561(2007)19:10(906)

23. Arel, H. Ş., and Aydin, E., "Use of Industrial and Agricultural Wastes in Construction Concrete," ACI Materials Journal, V. 115, No. 1, Jan. 2018 , pp. 55-64. doi: 10.14359/51700991

24. Gunasekara, C.; Setunge, S.; and Law, D. W., "Long-Term Mechanical Properties Of Different Fly Ash Geopolymers," ACI Structural Journal, V. 114, No. 3, 2017, May-June p. 743 doi: 10.14359/51689454

25. Gunasekara, C. M., "Influence of Properties of Fly Ash from Different Sources on the Mix Design and Performance of Geopolymer Concrete," RMIT University Melbourne, Melbourne, Australia, 2016.

26. Lloyd, N. A., and Rangan, B. V., "Geopolymer Concrete with Fly Ash, in Second International Conference on Sustainable Construction Materials and Technologies," Universita Politecnica delle Marche, Ancona, Italy, 2010.

27. Provis, J. L., "Geopolymers and Other Alkali Activated Materials: Why, How, and What?" Materials and Structures, V. 47, No. 1-2, 2014, pp. 11-25. doi: 10.1617/s11527-013-0211-5
28. Davidovits, J., "Geopolymer Chemistry and Sustainable Development. The Poly (Sialate) Terminology: A Very Useful and Simple Model for the Promotion and Understanding Of Green-Chemistry," Proceedings of 2005 Geopolymer Conference, 2005.

29. Gunasekera, C.; Setunge, S.; and Law, D. W., "Correlations between Mechanical Properties of Low-Calcium Fly Ash Geopolymer Concretes," Journal of Materials in Civil Engineering, ASCE, V. 29, No. 9, 2017, p. 04017111 doi: 10.1061/(ASCE)MT.1943-5533.0001916

30. ASTM C150/C150M-16, "Standard Specification for Portland Cement," ASTM International, West Conshohocken, PA, 2016, 10 pp.

31. AS 3582.1-1998, "Supplementary Cementitious Materials for Use with Portland and Blended Cement, Part 1: Fly Ash," Standards Australia, Sydney, Australia, 1998, 13 pp.

32. AS 1672-1997, "Limes and Limestones," Standards Australia, Sydney, Australia, 1997, 8 pp.

33. AS 1141.5-2000 (R2016), "Methods for Sampling and Testing Aggregates, Method 5: Particle Density and Water Absorption of Fine Aggregate," Standards Australia, Sydney, Australia, 2000, 8 pp.

34. ASTM C618-12, "Standard Specification for Coal Fly Ash and Raw or Calcined Natural Pozzolan for Use in Concrete," ASTM International, West Conshohocken, PA, 2012, 3 pp.

35. ASTM C311-96, "Standard Test Methods for Sampling and Testing Fly Ash or Natural Pozzolans for Use in Portland-Cement Concrete," ASTM International, West Conshohocken, PA, 1996, 9 pp.

36. Dunstan, E., and Zayed, A., "A Logical Pozzolanic Index and Its Use in Concrete Proportioning," Journal of ASTM International, V. 3, No. 4, 2006, pp. 1-12.

37. Neville, A. M., Properties of Concrete, fourth and final edition, Pearson Education Limited, Harlow, 1996, 844 pp.

38. AS 1012.3.1:2014, "Determination of Properties Related to the Consistency of Concrete-Slump Test," Standards Australia, Sydney, Australia, 2014.

39. AS 1012.9:2014, "Method of Testing Concrete, Method 9: Determination of the Compressive Strength of Concrete Specimens," Standards Australia, Sydney, Australia, 1999, 12 pp.

40. Neville, A. M., Properties of Concrete, fifth edition, Pearson Education Ltd., UK, 2011.

41. Xu, Q.; Hu, J.; Ruiz, J. M.; Wang, K.; and Ge, Z., "Isothermal Calorimetry Tests and Modeling of Cement Hydration Parameters," Thermochimica Acta, V. 499, No. 1-2, 2010, pp. 91-99. doi: 10.1016/j.tca.2009.11.007

42. Sofi, M.; Lumantarna, E.; Zhou, Z.; San Nicolas, R.; and Mendis, P., "From Hydration to Strength Properties of Fly Ash Based Mortar," Journal of Materials Science and Chemical Engineering, V. 5, No. 12, 2017, pp. 63-78. doi: 10.4236/msce.2017.512006

43. Tanesi, J., and Ardani, A., "Isothermal Calorimetry as a Tool to Evaluate Early-Age Performance of Fly Ash Mixtures," Transportation Research Record: Journal of the Transportation Research Board, V. 2342, No. 1, 2013, pp. 42-53. doi: 10.3141/2342-06

44. Deboucha, W.; Leklou, N.; Khelidj, A.; and Oudjit, M. N., "Hydration Development of Mineral Additives Blended Cement Using Thermogravimetric Analysis (TGA): Methodology of Calculating the Degree of Hydration," Construction and Building Materials, V. 146, 2017, pp. 687-701. doi: 10.1016/j.conbuildmat.2017.04.132

45. Steveson, M., and Sagoe-Crentsil, K., "Relationships between Composition, Structure and Strength of Inorganic Polymers," Journal of Materials Science, V. 40, No. 16, 2005, pp. 4247-4259. doi: 10.1007/ s10853-005-2794-x 
